\title{
,DEIXIS AND REFERENCE ANALYSIS IN JAKARTA POST: A CONTENT ANALYSIS RESEARCH
}

\author{
Syafryadin, Eka Apriani, Rita Inderawati, Wawan Tarwana, Haryani \\ University of Bengkulu \\ Institut Agama Islam Negeri (IAIN) Curup \\ Universitas Sriwijaya \\ Universitas Galuh \\ Politeknik Bumi Akpelni \\ syafryadin@unib.ac.id,eka.apriani@iaincurup.ac.id,ritarudisaid@yahoo.com,wtarwana@gmail.com, \\ haryani@akpelni.ac.id
}

Submitted: 2020-12-25

Accepted: 2021-10-11

\begin{abstract}
Deixis and reference are parts of pragmatics. These issues are needed to be known by the readers. Deixis and reference were existing in written or spoken language and those materials are learnt by students in university level especially in English education department. These things are essential to be known by the readers or audience. Thus, the aims of the study were to analyse the deixis and reference types in Jakarta Post. The research methodology was a qualitative research with content analysis. The instruments were checklist and document. Those were validated by triangulation. There were 90 articles of Jakarta Post to be analysed by using a thematic analysis. The steps were familiarization, coding, generating themes, defining and naming themes and writing up stage. The results showed that all types of dexis were found in Jakarta Post namely person, Spatial, time, discourse and social. In detail, 300 words of person deixis, 140 Spatial deixis, 90 time deixis, 30 social and 15 discouse deixis. The dominant type was person deixis. Another result was reference. The anaphoric and cataphoric reference were found in Jakarta Post, where the dominant one is anaphoric reference. In short, most of authors in Jakarta Post used person deixis and anaphoric reference to give clear information about the written text.
\end{abstract}

Keywords: deixis; reference; jakarta post

\section{INTRODUCTION}

Deixis is one of pragmatics materials that must be noticed by many people. Deixis has a function to give clear information about the sentence or utterance (Yule, 1996). Besides, Deixis contributes to the reader's understanding because deixis contains person, times, place, social and discourse which reveals the text. Deixis can be found in the novel, newspaper, poetry, lyrics, speech and so on. Besides, deixis is a part of pragmatics that point a language. The deixis could be found in written or oral form. There are several types of deixis namely person deixis, Spatial, time, social and discouse. Person deixis is a dexis that shows a person. This deixis usually refers to the personal pronoun. For example, I, you, we, they, he, she, it and etc. Spatial deixis is a dexis that shows the place, e.g restaurant, here, there, go to bed, cinema, and etc. Time or Spatial deixis is a deixis that shows the time of the event. For instance, now, today, tomorrow, Sunday, and etc. Social deixis is a deixis that shows the social status of the person. For example, your majesty, your highness, and etc. Discourse deixis is a dexis that shows tha discouse of the thing, e.g. here and there. 
Not only Deixis, reference is also important to be known. Reference is one of the pragmatics aspect that should be known by the students. Reference is as an act in which a speaker or writer uses a linguistic forms to enable a listener or reader to identify something. The reference can be anaphoric and cataphoric. Anaphoric reference is a reference in which the information of the subject has been clear in the beginning of the sentence. For example, Anita is my sister. She is very smart. In this sentence, "She" refers to "Anita". While, cataphoric reference is a reference where the information of the doer of the sentence will be clear in the following sentence. For instance, I turned the corner and almost stepped on it. There was a large snake in the middle of the path. In this sentence, it refers to snake. It is vice versa with anaphoric in terms of the pattern (Yule, 1996).

Many researchers had analysed the types of deixis in novel, poetry, song lyrics, newspaper, teachers' talk, students' talk, drama and speech from 2014 until 2020. Their results were almost the same, where Some researchers found about person, place, time deixis (Quinto, 2014; Sari, 2015; Nugarah, 2015; Purba, 2015; Hasanah, 2016; Asy'ari, Rita, Usman, 2017; Putri \& Budiarsa, 2018; Wibowo \& Nailufar, 2019; Rahayu \& Kurniawan, 2019; Laia, 2020), while several found other types of deixis, such as discourse and social deixis (Wahyudi, 2014; Widayanti \& Yuwono, 2017; Retnowati, Nasution, Setiadi, Ilza, 2018). Besides, other relevant studies compared person deixis among two languages and English teachers, where the results showed that English teachers were dominant in using person deixis (Novianty, Saleh , Sukmawati, 2018; Mayori, Putra, Suarnajaya , 2020). In line with those studies, Hong-mei, Dan, Dan-wu (2016) also discussed about person deixis, but they did not compare. They just wanted to see the adaptability of person deixis in English teacher talk. Latupeirissa (2016) identified person deixis in Korbafo dialect in Rote language. He found that there are three kinds of person deixis in Korbafo dialect namely singular and plural form of first, second and third person. The personal deixis on singular forms comprising the speaker Au (1 Singular), the addressee/ hearer Ko (II Singular), and the non-speaker Ndia (III Singular). The personal deixis on plural forms comprising; Ita (I Plural Incl), Ami (I Plural Excl), Kemi (II Plural), Sila (III Plural). In addition, Jumaedah, Saleh \& Harton (2020) investigated the effect of deixis used by teacher for students' understanding. Deixis could influence the students understanding about the material given by the teacher. Therefore, the teacher must optimize using dexis in the teaching and learning process.

The current research wants to investigate the deixis types and reference types in Jakarta Post because Jakarta Post is a reputable newspaper which not only covers national news, but also international news in the world. The Jakarta Post is published every day except Saturday, Sunday or holiday. The current research is not the same as the previous studies because the current research does not only analyse the types of deixis, but also the reference. Most of the relevant research analysed deixis in Novel, Song and local language. Deixis and reference are important to be researched because deixes could reference could increase the readers' understanding about the text. 


\section{METHOD}

Thirty editions of Jakarta Post in April 2020 were collected to achieve the objectives of the research. This document is useful for this content analysis of qualitative research because the researcher aimed at analysing deixis and reference of the Jakarta Post. As Creswell (2014) and Ary, Jacobs, Sorensen, \& Razavieh (2010) revealed out that content analysis is a qualitative research that suitable for analysing the document. The sampling technique was a purposive sampling because it is in relation to the purpose of the research.

The instruments of the research were checklist and document. The validation of instruments was undertaken by doing triangulation. The procedures of collecting data were (1) Contacting newspaper seller, (2) gathering the Jakarta Post for April edition from $1^{\text {st }}$ until $30^{\text {th }}$ of April, (3) Electing randomly 3 articles for every edition of Jakarta Post, (4) using checklist to see the deixis and reference for every article. The researcher did by himself to collect the data.

Furthermore, the data were analysed by using thematic analysis. According to Heigham \& Crocker (2009), thematic analysis is a qualitative data analysis that emphasizing on identifying, analysing, and interpreting the data. In general, there are six steps for thematic analysis. The first is familiarization that research must know the data from checklist and document. The second, a coding is a must to identify the deixis and reference in Jakarta Post. The third, generating themes means that the researcher decide the theme which covers dexis and reference types. The fourth, defining and naming themes are important to do for labelling. The fifth, writing up stage is essential to undertake because in this step, the researcher wrote the deixis and the reference analysis that had been identified and classified in Jakarta Post.

\section{FINDING AND DISCUSSION [Times New Roman 11 bold]}

\section{Findings}

The results of this study are accordance with the research questions or objectives. Those are deixis and reference in Jakarta Post. The results are obtained by checklist and document analysis.

\section{Deixis Types}

Referring to the checklist and coding, the results of deixis could be seen in table 1

Table 1. Deixis types occurrence in Jakarta Post

\begin{tabular}{|l|l|c|}
\hline No. & Deixis Types & Frequency \\
\hline 1 & Person Deixis & 300 \\
\hline 2 & Spatial Deixis & 140 \\
\hline
\end{tabular}




\begin{tabular}{|l|l|c|}
\hline 3 & Time Deixis & 90 \\
\hline 4 & Social Deixis & 30 \\
\hline 5 & Discourse Deixis & 15 \\
\hline
\end{tabular}

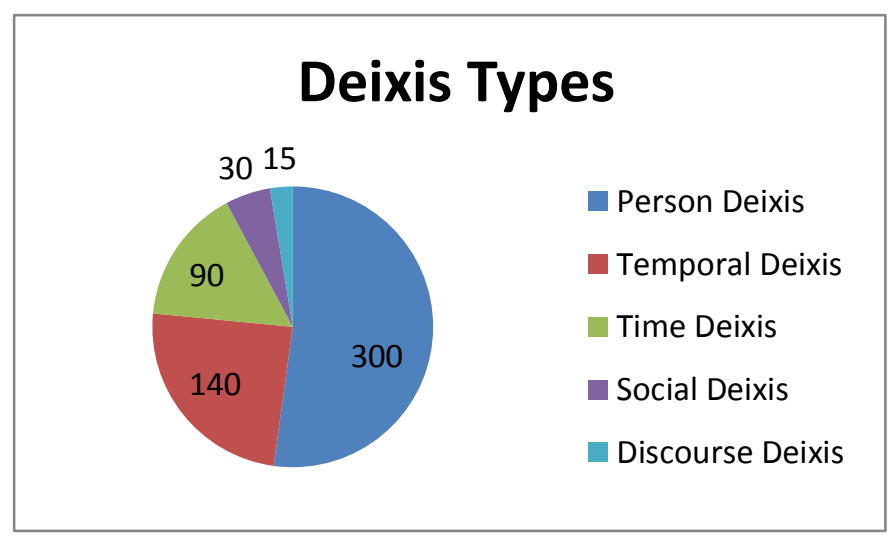

Graph 1

Table 1 or graph 1 shows that there are 300 words of person deixis, 140 Spatial deixis, 90 time deixis, 30 social and 15 discouse deixis found in the Opinion part of Jakarta Post. The dominant type is person deixis and the minority is discourse deixis. The examples of person deixis in Jakarta Post are Jordan, He, She, They, I, Them, you and etc. Spatial deixis are White House, Garden, office, police office, and etc. Then, the examples of time deixis are today, now, monday nowadays, tomorrow. The examples of social deixis are Miss, mister, your royal majesty. The examples of discourse deixis found in the text are this and that.

\section{Reference types}

The results of reference analysis could be seen in table 2 or graph 2 .

Table 2. Reference types occurrence in Jakarta Post

\begin{tabular}{|l|l|c|}
\hline No. & Deixis Types & Frequency \\
\hline 1 & Anaphoric & 195 \\
\hline 2 & Cataphoric & 95 \\
\hline
\end{tabular}

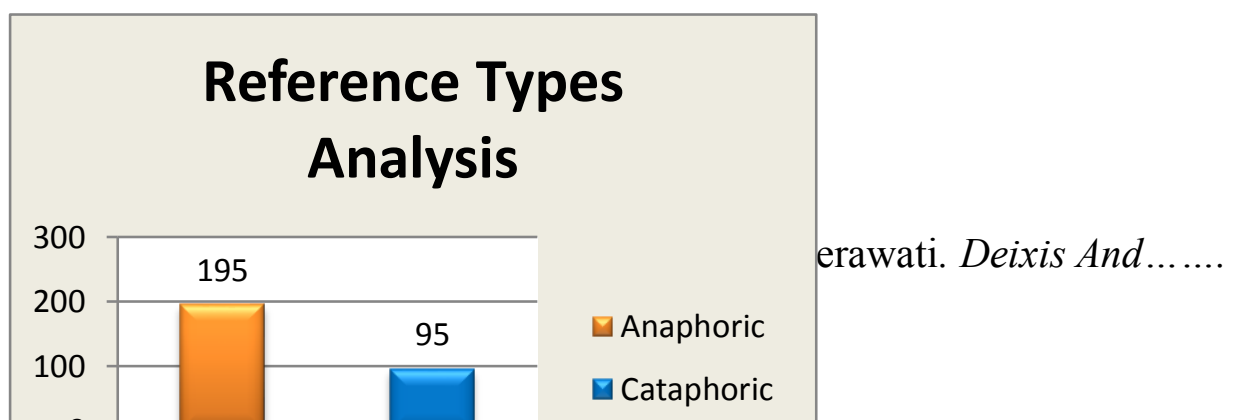


Table 2 or graph 2 shows that the frequency of anaphoric references found in Jakarta Post is 195 words, while the cataphoric reference is 95 . This means that anaphoric is more dominant than cataphoric reference. Those types of references are commonly found in a written text. The examples of anaphoric reference found in Jakarta Post are "Alizadeh, 21, who announced her defection on Instagram over the weekend", Boujjoufi said it was Alizadeh who had approached him about joining the group", Moeldoko, who was the Indonesian Military Commander at the time of the shooting, said that he did not think that the actions of the military personnel involved had been premeditated.". The examples of cataphoric references found in Jakarta Post are "Although President Joko Widodo did not command him, the assistant is still ", their best practice on tackling illegal fishing And drug trafficking are still admitted, although The coast guard from 6 Southeast Asian countries are doing their best. "The athlete is coming to the press conference. The president did not meet Liliana Natsir because the president has another meeting in different place."

\section{Discussion}

In relation to the findings of this research, the researcher divided discussion into two parts namely deixis analysis and reference analysis. Firstly, deixis analysis occurred in Jakarta Post covered all types of deixis from person deixis, time, place Deixis, social and discourse deixis. These findings are almost in line with the theory from Yule (1996) who stated that there are several types deixis that could be seen in the written or oral, such as person, Spatial, place and social. However, in Yule, there is no explanation about discourse deixis. The person deixis is the dominant one in the articles of Jakarta Post. This finding is supported by previous studies who found that person deixis is always found in written text or spoken one (Nasution, Setiadi, Ilza, 2018; Wibowo \& Nailufar, 2019; Rahayu \& Kurniawan, 2019; Laia, 2020). Deixis are in the article because deixis has a function to have the reader or listener more understanding about the text or utterance. The study by Jumaedah, Saleh \& Hartono (2020) stated that deixis has an impact on the reader or listeners' understanding. If the deixis exists in the sentence or utterance, the reader or listener is easy to get the meaning. 
Moreover, the less dominant of the types of deixis is discourse deixis. It is because discourse deixis is seldom to be used in oral or written text. Discourse could indicate the place, therefore, many people use a spatial deixis rather than discourse deixis. This finding is as the same as a study by Quinto, 2014; Wahyudi, 2014; Purba, 2015; Sari, 2015; Asy’ari, Rita, Usman, 2017 and Widayanti \& Yuwono, 2017 who were difficult to find out the discourse deixis in written text or newspaper.

The finding of this study is not only deixis types, but also references. Two types of references have been identified by the researcher. Those are anaphoric and catapohoric references. This is in line with the theory from Yule (1996) who revealed out about anaphoric and cataphoric references in text or oral form. The anaphoric references are more dominant than cataphoric. It is because the writers in Indonesia may always use anaphoric reference. This means that the writers of Indonesa in Jakarta Post always write the clear name or antecedent first and then the reference of the name or pronoun. Cataphoric reference is still seldom to be used in an article in Jakarta Post, it may because of avoiding misunderstanding. The references studies are still limited; therefore, the findings of this study could be different from the relevant studies.

\section{CONCLUSION}

In conclusion, all types of deixis are found in Jakarta Post, but the dominant one is person deixis. It may because when the writer wrote the sentence, the writer must write the subject first in order to make a reader know who is the doer. Those types of deixis are person, Spatial, time, social and discourse deixis. Another conclusion is the reference types in Jakarta Post namely anaphoric and cataphoric. The anaporic is more dominant than cataphoric reference.

\section{REFERENCES}

Ary, D., Jacobs, L.C., Sorensen, C. Razavieh, A. (2010). Introduction to Research in Education. Australia: Wadsworth Cengage Learning.

Asy'ari, M., Rita, F., Usman, S. (2017). An analysis of deixis in the novel Einsteins' dreams by Alan Lightman. Bahasasantodea. 5(1), 129-138.

Creswell, J. W. (2014). Research design: Qualitative, quantitative and mixed methods. approaches: Fourth edition. Thousand Oaks, CA: Sage Publications.

Hasanah, U. (2016). A pragmatic study on deixis in the lyric song. Published Thesis. UIN Maulana Malik Ibrahim. Malang, Jawa Timur.

Heigham, J \& Crocker. (2009). Qualitative Research in Applied Linguistics. UK: Palgrave

Hong-Mei, X., Dan, L., Dan-yu, W. (2016). A study on the adaptability of person deixis in English teacher talk. US-China Foreign Language. 14(12), 840-844. 
Jumaedah, N., Saleh, M., \& Hartono, R. (2020), The effect of teachers' use of deixis on students' understanding of their talk. English Educational Journal. 10(3), 361-365.

Laia, M.Y. (2020). Deixis in Charles Dicken's great expectation. Jurnal Education and Development Institut Pendidikan Tapanulis Selatan. 8(2), 332-335.

Latupeirissa, D.S. (2016). A study on personal deixis of Korbafo Dialect in Rote language. International Journal of Linguistics, Literature and Culture. 2(1), 11-16.

Mayori, W., Putra, N.A.J., Suarnajaya, I.W. (2020). A comparative study of deixis used by foreign and local English teachers in vocational high school. Journal of Education Research and Evaluation. 4(3), 121.

Nasution, D.B.A., Setiadi, G., Ilza, S.S. (2018). Deixis analysis in the song lyrics of Ed Sheeran's Divide Album. $2^{\text {nd }}$ English Language and Literature International Conference (ELLiC) Proceedings. 2, 376-382.

Novianty, F., Saleh, N.J., Sukmawati. (2018). A comparative study on personal deixis of English and Tukang Besi language. ELS Journal on Interdisciplinary Studies on Humanities. 1(2), 226-231.

Nugarah, D.S. (2015). Deixis analysis of the novel the twelfth card. Published Thesis. Universitas Muhammadiyah Surakarta. Jawa Tengah.

Putri, A., \& Budiarsa, M. (2018). The analysis of deixis in the novel The Fault in Our Stars by John Green. Jurnal Humanis, Fakultas Ilmu Budaya Unud. 22(3), 697-703.

Purba. R. (2015). Deixis in inaguration speech of president Susilo Bambang Yudhoyono. Jurnal Mantik Penusa. 17(1), 75-85.

Quinto, E.J.M. (2014). Stylistic analysis of deictic of expressions in president Benigno Aquino III's October $30^{\text {th }}$ speech. 3L: The Southeast Asian Journal of English Language Studies. 20(2), 2.

Rahayu, I.D., \& Kurniawan, E. (2019). Deixis investigation of motivational speech in Jack Ma's empowering young African entrepreneur in Nairobi's speech. Advances in Social Science Education and Humanities Research, Twelfth Conference on Applied Linguistics (CONAPLIN). 430, 102-106.

Retnowati, R. (2019). Deixis in Donald Trump's Speech to UN general assembly. Lingua Didaktika. 13 (2), 109-122.

Sari, R. (2015). Deixis analysis through the interaction among the students with different culture. Transformatika. 11 (2), 41.

Wahyudi. (2014). Pragmatics study on deixis in the Jakarta post editorial. Jurnal Penelitian Humaniora. 15(2), 111-120.

Wibowo, A.Y., \& Nailufar, N. (2018). Deixis and its context used in "Girl in Pieces" novel by Kathleen Glasglow. Wanastra. 10(2), 73-84.

Widayanti, S.R., \& Yuwono, S.E. (2017). A semantic analysis of Deixis in drama written by Lucille Fletcher. Laporan Penelitian Universitas Widya Dharma Klaten. 